\title{
MicroRNAs in the development and neoplasia of the
}

\section{mammary gland [version 1; peer review: 1 approved, 2}

\section{approved with reservations]}

\author{
Manoj Kumar Jena (iD
}

Department of Biotechnology, School of Bioengineering and Biosciences, Lovely Professional University (LPU), Phagwara, Punjab, 144411, India

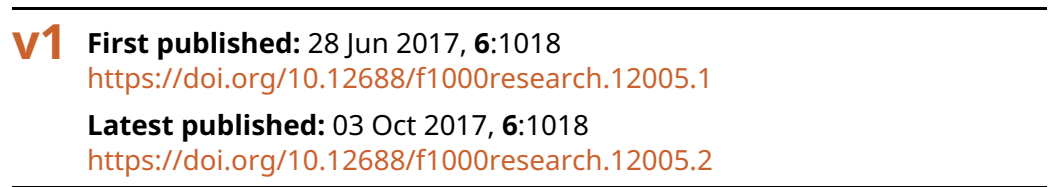

\section{Abstract}

Study on the role of microRNAs (miRs) as regulators of gene expression through posttranscriptional gene silencing is currently gaining much interest, due to their wide involvement in different physiological processes. Understanding mammary gland development, lactation, and neoplasia in relation to miRs is essential. miR expression profiling of the mammary gland from different species in various developmental stages shows their role as critical regulators of development. miRs such as miR-126, miR-150, and miR-145 have been shown to be involved in lipid metabolism during lactation. In addition, lactogenic hormones influence miR expression as evidenced by overexpression of miR-148a in cow mammary epithelial cells, leading to enhanced lactation. Similarly, the miR-29 family modulates lactation-related gene expression by regulating DNA methylation of their promoters. Besides their role in development, lactation and involution, miRs are responsible for breast cancer development. Perturbed estrogen (E2) signaling is one of the major causes of breast cancer. Increased E2 levels cause altered expression of ERa, and ERamiR cross-talk promotes tumour progression. miRs, such as miR-206, miR-34a, miR-17-5p, and miR-125 a/b are found to be tumour suppressors; whereas miR-21, miR-10B, and miR-155 are oncogenes.Studies using an ACI rat model showed similar findings of miR dysregulation due to excess E2, and a natural phenol antioxidant ellagic acid showed therapeutic properties by reversing the miR dysregulation. This review focuses on the recent findings concerning the role of miRs in developmental stages of the mammary gland (mainly lactation and involution stages) and their involvement in breast cancer progression. Further studies in this area will help us understand the molecular details of mammary gland biology, as well as miRs that could be therapeutic targets of breast cancer.

\section{Keywords}

Mammary gland, miRNA, development, lactation, neoplasia

\section{Open Peer Review \\ Approval Status $\checkmark$ ? \\ 12 \\ 23 \\ version 2 \\ (revision) \\ 03 Oct 2017 \\ version 1 \\ 28 Jun 2017

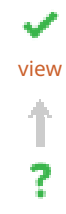

$\ldots \ldots$ \\ 1. Mohammed Alsaweed, Majmaah University, \\ Al Majma'ah, Saudi Arabia \\ 2. Shantibhusan Senapati, Institute of Life \\ Sciences, Bhubaneswar, India \\ 3. Bhudev C. Das, University of Delhi, New \\ Delhi, India}

Any reports and responses or comments on the article can be found at the end of the article. 
Corresponding author: Manoj Kumar Jena (drmanoj.jena@gmail.com)

Author roles: Jena MK: Conceptualization, Writing - Original Draft Preparation, Writing - Review \& Editing

Competing interests: No competing interests were disclosed.

Grant information: The author(s) declared that no grants were involved in supporting this work.

Copyright: @ 2017 Jena MK. This is an open access article distributed under the terms of the Creative Commons Attribution License, which permits unrestricted use, distribution, and reproduction in any medium, provided the original work is properly cited.

How to cite this article: Jena MK. MicroRNAs in the development and neoplasia of the mammary gland [version 1; peer review: 1 approved, 2 approved with reservations] F1000Research 2017, 6:1018 https://doi.org/10.12688/f1000research.12005.1

First published: 28 Jun 2017, 6:1018 https://doi.org/10.12688/f1000research.12005.1 


\section{Introduction}

MicroRNAs (miRs) are small, endogenous noncoding RNAs that regulate gene expression post-transcription, by degrading target mRNA or repressing translation. They are hardy in nature, being resistant to RNAse degradation, acidic $\mathrm{pH}$, and repeated freezing and thawing, and are stable at room temperature ${ }^{1}$. In addition to their involvement in many other physiological processes, they play crucial roles in mammary gland development and lactation, and their deregulation can lead to breast cancer ${ }^{2}$. This review provides an overview on the recent findings concerning the role of miRs in the developmental stages of the mammary gland and breast cancer progression.

\section{miRs in mammary glands}

The study of miRs in mammary gland development is essential, as miRs in milk are derived from the mammary gland and can be a biomarker of a healthy lactating gland, as well as protecting infants and promoting their development ${ }^{3}$. The role of miRs in milk is still being debated. For example, whether they are only simple nutrients or if they have some regulatory functions in milk recipients after entering systemic circulation is still disputed ${ }^{4}$.

Comparative analysis of the miRNome of bovine milk, mammary tissue, milk fat, and whey revealed $188 \mathrm{miRs}$ in common, with some novel miRs discovered ${ }^{5}$. The miR signature of milk fat was similar to that of mammary gland tissue miRs. Functional studies of highly expressed miRs in those fractions indicated their role as regulators of mammary gland functions contributing to healthy milk production ${ }^{5}$.

\section{miRs controlling lactation}

It was observed that miR-126 plays a role in mammary epithelial cells (MECs) by modulating lipid synthesis ${ }^{6}$. FASN (fatty acid synthase) gene expression is increased when miR-126-3p is inhibited, suggesting its involvement in lipid metabolism in the mammary gland. In addition, estradiol and progesterone enhanced lipid synthesis by downregulating the levels of miR-126-3p $\mathrm{p}^{6}$. Similarly, miR-150 hampers lipogenesis in MECs and reduces secretory activity $^{7}$, while miR-145 facilitates milk fat synthesis in lactating goats by targeting the gene INSIGI (insulin induced gene 1$)^{8}$.

The role that miRs play as regulators of lipogenesis was confirmed by overexpression studies, which showed that there was more synthesis of fat droplets, accumulating triacylglycerols, and a higher proportion of unsaturated fatty acids in lactating MECs. For instance, miR-24 was found to be expressed at a much higher level during peak lactation in goats and affects triacylglycerol content, unsaturated fatty acid concentration, and expression of target genes, such as FASN, SREBF1 (sterol regulatory element binding transcription factor1), $S C D$ (stearoyl-CoA desaturase), GPAM (glycerol-3-phosphate acyltransferase; mitochondrial), and ACACA (acetyl-CoA carboxylase) ${ }^{9}$.

miR expression in MECs is regulated by lactogenic hormones (dexamethasone, insulin, and prolactin), as evidenced by an increased miR-148a level in bovine MECs, which is probably associated with increased milk production during lactation in cows ${ }^{10}$. The miR-29 family affects lactation by regulating the DNA methylation of target genes DNMT3A and DNMT3B (DNA (cytosine-5)-methyltransferase $3 \mathrm{~A}$ and $3 \mathrm{~B}$ ) in MECs of dairy cows ${ }^{11}$. Moreover, inhibition of the miR-29 family resulted in hypermethylation of promoters of lactation-related genes, leading to decreased secretion of triglycerides, proteins, and lactose by the epithelial cells. miR-486 facilitates lactation by downregulating PTEN (phosphatase and tensin homolog) target gene. Downregulation of this gene affects the expression of downstream genes, such as AKT, mTOR and $\beta$-casein, which have crucial roles in mammary gland development and lactation ${ }^{12}$. Additionally, diet restriction has been shown to affect the miRNome of lactating mammary glands, indicating the role of miRs in regulating milk composition ${ }^{13}$.

\section{miRs controlling involution and breast cancer}

Identification and characterization of miRs involved in breast cancer will facilitate targeting miRs for possible therapy. Improper involution possibly contributes towards tumour development ${ }^{14}$. miR-424(322)/503 regulates mammary involution in humans by targeting BCL-2 (B-cell lymphoma 2; anti-apoptotic) and IGFIR (insulin like growth factor-1-receptor) genes. The loss of this miR leads to malignancy and nonresponse to chemotherapy, demonstrating its role as a tumour suppressor ${ }^{14}$. By contrast, some miRs, such as miR-660-5p, promote tumour development and metastasis, and the level of miR-660-5p was found to be increased in MCF7 breast cancer cell lines ${ }^{15}$. This miR's tumour promoting activity was confirmed by observation of reduced invasion of MCF7 cells at reduced miR-660-5p levels.

One of the major causes of breast cancer is disturbed estrogen signaling, where the altered expression of estrogen receptor $\alpha(\mathrm{ER} \alpha)$ and its cross-talk with the related miR culminates in neoplasia ${ }^{16}$. Studies on the effect of E2 on the expression pattern of miRs in MCF7 and ZR75 cell lines revealed 172 miRs that were up or downregulated. Notable miRs are miR-206, miR-34a, miR-17-5p, and miR-125 a/b, which act as tumour suppressors, and miR-21, miR-10B, and miR-155, which act as oncogenes ${ }^{17}$. Another study using an ACI rat model for the effect of E2 on the miR signature showed 33 dysregulated miRs ${ }^{18}$. Additionally, the use of ellagic acid (natural phenol antioxidant) reversed the dysregulation of miR-206, miR-182, miR-375, miR-127, miR-183, and miR-122, subsequently modulating the target proteins ER $\alpha$, RASD1, cyclin D1, FoxO1, FoxO3a, Bcl-w, Bcl-2 and cyclin G118 ${ }^{18}$. Furthermore, overexpression of the tumour suppressing miR-133a in MCF-7 and MDA-MB-231 cells suppressed phosphorylated Akt (p-Akt) protein and inhibited p-Akt nuclear translocation, and this miR also regulates the cell cycle of cancerous cells by targeting the EGFR (epidermal growth factor receptor) gene ${ }^{19}$.

miR-206 is found to play a crucial role in BRCAl (Breast CAncer susceptibility gene; tumour suppressor) depleted mouse mammary gland ${ }^{20}$. Overexpression of miR-206 showed no effect on lactation, but did have a role in tissue remodeling through increasing fat tissue and reducing branching morphogenesis. There may be a possibility of increased miR-206 levels due to BRCA1 loss, culminating in mammary gland remodeling and tumour development $^{20}$. miR-184 is found to be a tumour suppressor by regulating the number of genes in the $\mathrm{PI} 3 \mathrm{~K} / \mathrm{AKT} / \mathrm{mTOR}$ pathway, 
as observed by miR profiling of the pubertal mouse mammary gland $^{21}$. This pathway is important in mammary gland development and lactation ${ }^{22}$. miR-184 is only expressed in epithelial cells, and the level increases during differentiation of cells from terminal end bud into ductal epithelial cells ${ }^{21}$.

\section{Conclusions}

miRs have been shown to be one of the major regulators of mammary gland development and neoplasia. miRNome studies of mammary gland in different developmental stages and cancerous tissues will elucidate biomarkers for early cancer diagnosis, and may be used as therapeutic targets. Future studies focusing on the cross-talk between miRs and target genes with the signaling pathways involved in development and neoplasia of mammary gland will open the door to understand mammary gland biology and oncogenesis in molecular detail.

\section{Competing interests}

No competing interests were disclosed.

\section{Grant information}

The author(s) declared that no grants were involved in supporting this work.
1. Gigli I, Maizon DO: microRNAs and the mammary gland: A new understanding of gene expression. Genet Mol Biol. 2013; 36(4): 465-474. PubMed Abstract | Publisher Full Text | Free Full Text

2. Wang $\mathrm{CD}$, Long $\mathrm{K}$, Jin $\mathrm{L}$, et al.: Identification of conserved microRNAs in peripheral blood from giant panda: expression of mammary gland-related microRNAs during late pregnancy and early lactation. Genet Mol Res. 2015; 14(4): 14216-14228.

PubMed Abstract | Publisher Full Text

3. Alsaweed M, Lai CT, Hartmann PE, et al:: Human milk miRNAs primarily originate from the mammary gland resulting in unique miRNA profiles of fractionated milk. Sci Rep. 2016; 6: 20680.

PubMed Abstract | Publisher Full Text | Free Full Text

4. Melnik BC, Kakulas F, Geddes DT, et al.: Milk miRNAs: simple nutrients or systemic functional regulators? NutrMetab (Lond). 2016; 13: 42. PubMed Abstract | Publisher Full Text | Free Full Text

5. Li R, Dudemaine PL, Zhao X, et al:: Comparative Analysis of the miRNome of Bovine Milk Fat, Whey and Cells. PLoS One. 2016; 11(4): e0154129. PubMed Abstract | Publisher Full Text | Free Full Text

6. Chu M, Zhao $\mathrm{Y}$, Feng $\mathrm{Y}$, et al.: MicroRNA-126 participates in lipid metabolism in mammary epithelial cells. Mol Cell Endocrinol. 2017; pii: S0303-7207(17)30309-X, In press.

PubMed Abstract | Publisher Full Text

7. Heinz RE, Rudolph MC, Ramanathan P, et al:: Constitutive expression of microRNA-150 in mammary epithelium suppresses secretory activation and impairs de novo lipogenesis. Development. 2016; 143(22): 4236-4248. PubMed Abstract | Publisher Full Text | Free Full Text

8. Wang $\mathrm{H}$, Shi H, Luo J, et al:: MiR-145 Regulates Lipogenesis in Goat Mammary Cells Via Targeting INSIG1 and Epigenetic Regulation of Lipid-Related Genes. J Cell Physiol. 2017; 232(5): 1030-1040.

PubMed Abstract | Publisher Full Text

9. Wang $\mathrm{H}$, Luo J, Chen Z, et al.: MicroRNA-24 can control triacylglycerol synthesis in goat mammary epithelial cells by targeting the fatty acid synthase gene. J Dairy Sci. 2015; 98(12): 9001-14. PubMed Abstract | Publisher Full Text

10. Muroya S, Hagi T, Kimura A, et al.: Lactogenic hormones alter cellular and extracellular microRNA expression in bovine mammary epithelial cell culture. J Anim Sci Biotechnol. 2016; 7: 8.

PubMed Abstract | Publisher Full Text | Free Full Text

11. Bian Y, Lei $Y$, Wang C, et al.: Epigenetic Regulation of miR-29s Affects the Lactation Activity of Dairy Cow Mammary Epithelial Cells. J Cell Physiol. 2015; 230(9): 2152-63.

PubMed Abstract | Publisher Full Text
12. Li D, Xie X, Wang J, et al: MiR-486 Regulates Lactation and Targets the PTEN Gene in Cow Mammary Glands. PLOS One. 2015; 10(3): e0118284. PubMed Abstract | Publisher Full Text | Free Full Text

13. Mobuchon L, Marthey S, Le Guillou S, et al:: Food Deprivation Affects the miRNome in the Lactating Goat Mammary Gland. PLoS One. 2015; 10(10): e0140111.

PubMed Abstract | Publisher Full Text | Free Full Text

14. Rodriguez-Barrueco $R$, Nekritz EA, Bertucci $F$, et al: miR-424(322)/503 is a breast cancer tumor suppressor whose loss promotes resistance to chemotherapy. Genes Dev. 2017; 31(6): 553-566.

PubMed Abstract | Publisher Full Text | Free Full Text

15. Shen $Y, Y e$ YF, Ruan LW, et al.: Inhibition of miR-660-5p expression suppresses tumor development and metastasis in human breast cancer. Genet Mol Res. 2017; 16(1): gmr16019479.

PubMed Abstract | Publisher Full Text

16. Manavathi B, Dey O, Gajulapalli VN, et al.: Derailed estrogen signaling and breast cancer: an authentic couple. Endocr Rev. 2013; 34(1): 1-32. PubMed Abstract | Publisher Full Text | Free Full Text

17. Ferraro L, Ravo M, Nassa G, et al.: Effects of oestrogen on microRNA expression in hormone-responsive breast cancer cells. Horm Cancer. 2012; 3(3): $65-78$

PubMed Abstract | Publisher Full Text

18. Munagala R, Aqil F, Vadhanam MV, et al:: MicroRNA 'signature' during estrogen-mediated mammary carcinogenesis and its reversal by ellagic acid intervention. Cancer Lett. 2013; 339(2): 175-84.

PubMed Abstract | Publisher Full Text | Free Full Text

19. Cui W, Zhang S, Shan C, et al:: MicroRNA-133a regulates the cell cycle and proliferation of breast cancer cells by targeting epidermal growth factor receptor through the EGFR/Akt signaling pathway. FEBS J. 2013; 280(16): 3962-74.

PubMed Abstract | Publisher Full Text

20. Wronski A, Sandhu GK, Milevskiy MJ, et al.: MicroRNA-206 is differentially expressed in Brca1-deficient mice and regulates epithelial and stromal cell compartments of the mouse mammary gland. Oncogenesis. 2016; 5: e218. PubMed Abstract | Publisher Full Text | Free Full Text

21. Phua YW, Nguyen A, Roden DL, et al:: MicroRNA profiling of the pubertal mouse mammary gland identifies miR-184 as a candidate breast tumour suppressor gene. Breast Cancer Res. 2015; 17: 83. PubMed Abstract | Publisher Full Text | Free Full Text

22. Wang Z, Hou X, Qu B, et al.: Pten Regulates Development and Lactation in the Mammary Glands of Dairy Cows. PLoS One. 2014; 9(7): e102118. PubMed Abstract | Publisher Full Text | Free Full Text 


\title{
Open Peer Review
}

\section{Current Peer Review Status: ? $\checkmark$}

Version 1

Reviewer Report 20 September 2017

https://doi.org/10.5256/f1000research.12984.r24742

(C) 2017 Das B. This is an open access peer review report distributed under the terms of the Creative Commons Attribution License, which permits unrestricted use, distribution, and reproduction in any medium, provided the original work is properly cited.

\begin{abstract}
Bhudev C. Das
Molecular Oncology Laboratory, B.R. Ambedkar Centre for Biomedical Research (ACBR), University of Delhi, New Delhi, India

Review article on "MicroRNAs in the development and neoplasia of the mammary gland" submitted by M.K. Jena deals with how various microRNAs that regulate gene expression through post transcriptional gene silencing are important during development and progression as well as prognosis of cancer of the mammary gland in women. Though I understand it is a mini-review but it has not been written in a very focused and systematic way. There are huge numbers of publications in this field, particularly the role of mRNA in breast carcinogenesis. However, the author cites only 22 references in this article which is highly inadequate to justify the review on the role of miRNA in mammary gland development and carcinogenesis. Author must consult recently published literatures including a recent paper by Thakur et al. (2016) ${ }^{1}$ and many of the references therein. There are a lot of sweeping comments have been made which indicates that the author has nothing much to do with cancer specialty. The comments in abstract say 'miRs are responsible for breast cancer development'. It is not straight forward and clear that miRNA are responsible of breast cancer development. They may be associated with but not directly correlated with cancer development. Similar sweeping comments are many in the text and these need to be addressed properly and the manuscript needs to be elaborative and focused. The presentation of the review article should be made with proper sub-headings on mammary gland development, lactation and carcinogenesis.
\end{abstract}

In summary, I suggest that the article can be considered for indexing only after satisfactory revision.

\section{References}

1. Thakur S, Grover RK, Gupta S, Yadav AK, et al.: Identification of Specific miRNA Signature in Paired Sera and Tissue Samples of Indian Women with Triple Negative Breast Cancer.PLoS One. 2016; 11 (7): e0158946 PubMed Abstract | Publisher Full Text

Is the topic of the review discussed comprehensively in the context of the current 


\section{literature?}

Yes

Are all factual statements correct and adequately supported by citations? Partly

Is the review written in accessible language?

Partly

Are the conclusions drawn appropriate in the context of the current research literature? Partly

Competing Interests: No competing interests were disclosed.

Reviewer Expertise: Molecular oncologist

I confirm that I have read this submission and believe that I have an appropriate level of expertise to confirm that it is of an acceptable scientific standard, however I have significant reservations, as outlined above.

Author Response 01 Oct 2017

Manoj Jena, Lovely Professional University (LPU), Phagwara, India

All the suggestions made by the referee has been complied in the second version of this article.

Competing Interests: No competing interests were disclosed.

Reviewer Report 19 September 2017

https://doi.org/10.5256/f1000research.12984.r25931

(c) 2017 Senapati S. This is an open access peer review report distributed under the terms of the Creative Commons Attribution License, which permits unrestricted use, distribution, and reproduction in any medium, provided the original work is properly cited.

\section{Shantibhusan Senapati}

Tumor Microenvironment and Animal Models Lab, Institute of Life Sciences, Bhubaneswar, Odisha, India

With this review, the author provide a concise literature summary of microRNAs in the development and neoplasia of the mammary gland. For the most part the review is complete and informative. To further improve the quality, the author is advised to address these minor points:

1. Exosomes secreted by different cells of mammary gland carry microRNA. It has been demonstrated that cancer-associated fibroblasts release exosomal microRNA that induce 
aggressiveness in breast cancer cells (e.g. Donnarumma et al. $(2017)^{1}$ ). At the same time, the microRNA present in the exosomes secreted by the cancer cells also play a critical role in the pathogenesis of breast cancer (e.g. Melo et al. $\left.(2014)^{2}\right)$. Hence, the authors might consider to include these information.

2. The beginning sentence under "miRs in mammary gland" heading needs to be restructured. The presence of miRNA in milk and the role of miRNA in mammary development should be mentioned separately.

3. In the abstract, the sentence "Further studies in this area will help us understand ......" should be "Further studies in this area will help us to understand ......").

\section{References}

1. Donnarumma E, Fiore D, Nappa M, Roscigno G, et al.: Cancer-associated fibroblasts release exosomal microRNAs that dictate an aggressive phenotype in breast cancer.Oncotarget. 2017; 8 (12): 19592-19608 PubMed Abstract | Publisher Full Text

2. Melo SA, Sugimoto H, O'Connell JT, Kato N, et al.: Cancer exosomes perform cell-independent microRNA biogenesis and promote tumorigenesis.Cancer Cell. 2014; 26 (5): 707-21 PubMed Abstract | Publisher Full Text

Is the topic of the review discussed comprehensively in the context of the current literature?

Yes

Are all factual statements correct and adequately supported by citations?

Yes

Is the review written in accessible language?

Yes

Are the conclusions drawn appropriate in the context of the current research literature? Yes

Competing Interests: No competing interests were disclosed.

Reviewer Expertise: Tumor microenvironment, animal models, stroma and cancer cell crosstalk

I confirm that I have read this submission and believe that I have an appropriate level of expertise to confirm that it is of an acceptable scientific standard.

Author Response 22 Sep 2017

Manoj Jena, Lovely Professional University (LPU), Phagwara, India

To be incorporated in the heading "miRs controlling involution and breast cancer":

Exosomes are cell - derived small vesicles (40 - $100 \mathrm{~nm}$ ) containing mRNA, protein, miR etc. 
They are crucial mediator of inter cellular signaling during cancer development. Exosomes derived from cancer associated fibroblasts in breast cancer have 3 miRs such as miR-21, 143 , and -378 e which promote stemness, epithelial-mesenchymal transition, and anchorage-independent cell growth, thus accelerating oncogenic signaling in breast cancer cells (Donnarumma et al., 2017). The exosomes released from cancer cells of breast cancer patients induce the non-tumorigenic epithelial cells to form tumors with the help of dicer endonuclease (Melo et al., 2014).

The beginning sentence under "miRs in mammary gland" will be restructured. The presence of miRNA in milk and the role of miRNA in mammary development will be separated.

In the abstract, the sentence "Further studies in this area will help us understand ......" will be rectified as "Further studies in this area will help us to understand ......".

Competing Interests: No competing interests were disclosed.

Reviewer Report 07 August 2017

https://doi.org/10.5256/f1000research.12984.r24612

(C) 2017 Alsaweed M. This is an open access peer review report distributed under the terms of the Creative Commons Attribution License, which permits unrestricted use, distribution, and reproduction in any medium, provided the original work is properly cited.

\section{Mohammed Alsaweed}

College of Applied Medical Sciences, Majmaah University, Al Majma'ah, Saudi Arabia

The review entitled "MicroRNAs in the development and neoplasia of the mammary gland" has briefly presented recent studies in the relevant studies in mammary gland microRNAs field. This kind of review is very good for scientists to update their knowledge without reading informative reviews. However, minor comments are below to make the review suitable for indexing:

Introduction:

More information is needed to understand the mechanism of microRNA roles in the mammary gland.

miRs in mammary gland:

Along with Alsaweed et al. study, Modepalli et al. (2014, BMC Genomics) has provided evidence that mammary gland is the main source of microRNAs in milk. Therefore, milk microRNAs are not considered as nutrients as stated, so better to not use "whether they are only simple nutrients".

Examples about the milk microRNAs are important as the mammary gland is synthesized and secreted milk.

miRs controlling lactation: 
Highly expressed microRNAs in milk/mammary gland have different roles in synthesize various milk nutrient contents such as triacylglycerols and lactose, so the role of highly expressed microRNAs must be linked to related functions (Alsaweed et al 2016, PLoS ONE and IJMS).

Li et al. (2012, BMC Genomics) has presented very important aspects of the microRNAs and lactation performance.

miRs controlling involution and breast cancer:

Zhang et al. (2013, Nature Cell Biology) has provided breast cancer inhibits progression by microRNAs expression roles, so it must be considered in this review.

Is the topic of the review discussed comprehensively in the context of the current literature?

Yes

Are all factual statements correct and adequately supported by citations?

Yes

Is the review written in accessible language?

Yes

Are the conclusions drawn appropriate in the context of the current research literature? Yes

Competing Interests: No competing interests were disclosed.

Reviewer Expertise: microRNA, gene expression regulation, lactation, mammary gland, milk, human milk

I confirm that I have read this submission and believe that I have an appropriate level of expertise to confirm that it is of an acceptable scientific standard, however I have significant reservations, as outlined above.

Author Response 09 Aug 2017

Manoj Jena, Lovely Professional University (LPU), Phagwara, India

\section{Introduction}

Mechanism of action to be incorporated: Matured miRs integrate into the RNA - induced silencing complex (RISC) and direct it to target mRNAs through partial sequence complementarity. miRs down regulate the target gene expression by translation repression (48 \% through RISC complex), or mRNA degradation (29\%), or by both phenomena (23\%). (Jin and Xiao, 2015).

miRs in mammary glands

To be removed: The role of miRs.........still disputed.

To be incorporated: miRs in milk during lactation are putative markers of activities in 
mammary gland and act as functional signals for proper growth and development of the young. The highly abundant miRs in milk during lactation cycle are miR-191, 184, 181, 148, 375 , and miRs of let-7 family ( $7 f, 7 a$ and $7 i)$ as evidenced from studies in the marsupial tammar wallaby (Modepalli et al., 2014).

\section{miRs controlling lactation}

To be incorporated: Lin et al (2013) observed group of miRs (such as miR-23a, 27b, 103, and 200a) affect milk fat synthesis with synergistic action. miR profiling of lactating and nonlactating bovine mammary gland revealed miR-125b, 181a, and 199b expression level reduced in non-lactation period; whereas miR-141, 484, and 500 expression level was higher in lactation period. (Li et al., 2012). Highly expressed miRs such as let-7f-5p is found to target many genes involved in protein, carbohydrate, and triglyceride synthesis. The human milk enriched miR such as miR-22-3P regulates development and differentiation of Tlymphocytes. The miR-181a-5p and miR-182-5p have crucial role in immune cell differentiation, miR-375 is required for glucose homeostasis, and miR-148a-3p is a tumour suppressor and involved in liver development (Alsaweed et al., 2016).

\section{miRs controlling involution and breast cancer}

To be incorporated: The miR 126/126* pair is observed to repress the recruitment of mesenchymal stem cells and inflammatory monocytes into the tumour stroma, thus inhibiting breast cancer metastasis (Zhang et al., 2013).

Competing Interests: No competing interests were disclosed.

The benefits of publishing with F1000Research:

- Your article is published within days, with no editorial bias

- You can publish traditional articles, null/negative results, case reports, data notes and more

- The peer review process is transparent and collaborative

- Your article is indexed in PubMed after passing peer review

- Dedicated customer support at every stage

For pre-submission enquiries, contact research@f1000.com 